\title{
The Influence of Principal Leadership and Work Ethic of Civil Servant Teachers on Teacher Performance
}

\author{
Amiati \\ SD Negeri Jaya Bakti Madang Suku 1, OKU Timur \\ e-mail: atiatiami0890@gmail.com \\ Muhammad Kristiawan \\ Universitas Bengkulu \\ e-mail: muhammadkristiawan@unib.ac.id \\ Dessy Wardiah \\ Universitas PGRI Palembang \\ e-mail: dessywardiah77@gmail.com \\ Article History: Received on 13 November 2021, Revised on 12 January 2022 \\ Published on 20 January 2022
}

\begin{abstract}
The function of principal leadership in the successful delivery of education in schools is critical. It is possible to optimize the work ethic of teachers in their tasks via strong leadership. It is considered that if leadership is carried out successfully and work ethic is ideal, it would be able to support instructors' good performance. As a result, the purpose of this study was to determine the impact of a principal's leadership and a teacher's work ethic on teacher performance. This study was carried out using quantitative research methodologies. According to the findings of this study, the principal's leadership and teacher work ethic had a favorable and substantial impact on the performance of state junior high school teachers, both partially and concurrently.
\end{abstract}

Keywords: Principal Leadership, Work Ethic, Teacher Performance

\section{A. Introduction}

One of the educational issues confronting the Indonesian country is the inadequate quality of education at all levels and units of education, particularly basic and secondary school. Various efforts have been undertaken to improve the quality of education, including teacher training and competency development, the acquisition of books and learning materials, the upgrading of educational facilities and infrastructure, and the improvement of school management quality. However, different indexes of educational quality have not improved significantly. Some schools have shown good outcomes, while the majority of others are still concerned (Rahmadi et al, 2021).

Education in Indonesia has experienced two fundamental shifts in response to societal needs and global advancements. First, the notion of school-based management is put into practice. The adoption of this idea is projected to make school education more democratic, and school management and development may be tailored to the conditions, needs of the community environment, and resources of each school. Second, the curriculum shifts from a materialfocused curriculum to a competency-based curriculum. This curriculum stresses that the learning process is based on certain competences that must be attained during the learning 
Volume 2 (3) 2021

E-ISSN: 2723-6919 P-ISSN: 2746-0827

process. This competency-based curriculum is focused on key competencies that students in every grade and school level must learn. Thus, the execution of the learning process is anticipated to ensure students' mastery of competence in the context of their environment.

The application of the idea of school-based management and the establishment of a competency-based curriculum necessitates modifications in assessment implementation. Implementation must be done thoroughly by empowering teachers and schools. To increase the quality of formal education, teachers, together with other factors like as facilities, curriculum, students, management, and book procurement, play an essential role. Because the center of education is teaching and learning, which requires the function of the teacher, the teacher is the key to the success of education (Firman et al, 2021; Susilawati et al, 2021).

According to Sudarminta (2000), teacher quality is not yet optimal, as evidenced by symptoms such as poor mastery of the material being taught; a disparity between the field of study the teacher is studying and the field being taught; a less effective method of teaching; a lack of teacher authority in front of students; a lack of motivation and dedication to become a genuine educator; and an increasing number of teachers who are not truly teachers. Most teachers continue to function as teachers rather than educators in their interactions with pupils.

Meanwhile, Sudjana and Ibrahim (2010) explain that the low public recognition of the teaching profession is caused by some people's belief that anyone can become a teacher as long as they are knowledgeable; a shortage of teachers in remote areas, which provides opportunities to appoint someone who does not have the expertise to become a teacher; and many teachers who do not appreciate, let alone try to develop, their profession. Feelings of inadequacy as a result of becoming a teacher, abuse of the profession for personal fulfillment and interests, resulting in a decline in the teacher's authority. Syah (2011) provided another point of view, emphasizing the poor level of professional competence among teachers. Teachers' grasp of teaching materials and procedures remains subpar.

As a result, one of the components that play a role in efforts to improve teachers' work ethic is to improve teachers' professionalism, which is characterized by mastering their duties, roles, and competencies, having a high commitment to their profession, and adhering to a learning paradigm not only in the classroom but also for themselves to carry out continuing education. The principal's leadership is one of the additional characteristics that impact teachers' work ethic.

Education implementation contributes to policy decentralization by ensuring that the community is included and participates in educational endeavors. The school principal's broader authority in providing education in schools, including not only formulating the school's vision and mission, but also the authority to formulate policies that directly touch on important internal school issues such as new student admissions, RAPBS, grade promotion norms, graduation norms, local content curriculum, and so on. The duties of administrators and instructors are becoming increasingly complex.

The principal's responsibilities include not just administering the school but also cooperating with and relating directly to the community. The principal is responsible for raising the spirit of the staff of teachers and school employees to work better, building and maintaining kinship, cohesiveness, and unity among teachers, employees, and student learning outcomes, developing a curriculum, knowing the school plan and knowing how to implement it, paying 
attention and seeking the welfare of teachers, and so on. This motivates any firm to improve its performance in order to continue to exist and grow in accordance with expectations. Similarly, school principal leadership is anticipated to exist and be able to maximize performance so that they can carry out program activities that provide excellent education. The principal, as the top leader with the most influence and who decides the school's growth, must have administrative skill, great dedication, and flexibility in carrying out his tasks. A competent principal's leadership must be capable of seeking to increase teacher performance through a capacity development program for educators. As a result, the principle must have the personality or characteristics, as well as the competencies and skills, to manage an educational institution. As a leader, the principle must be able to pay attention to the needs and sentiments of those who work in order to ensure that teacher performance is constantly maintained.

Instructors have diverse qualities and actions when it comes to educating students. Some are eager and full of duty, while others perform the work without a feeling of responsibility. There are also teachers who are frequently truant, arrive late, and defy orders. Teachers in such a state are an issue in every formal educational institution. Due to the presence of instructors who perform poorly, schools will struggle to attain the results that teachers anticipate.

According to Kristiawan (2017), the teacher's role is a predictor of the success of the education and learning mission in schools; the teacher is responsible for planning, leading, and establishing a conducive environment that motivates pupils to carry out the learning process. Teachers play an essential role in education and other educational resources; in other words, teachers are the driving force behind initiatives to enhance service quality and educational results. Teacher performance has a direct impact on the level of education received by each student; the better the teacher's performance, the higher the quality of education generated; in other words, if the teacher performs well, the outcomes of the teaching and learning process will be satisfactory.

A teacher is a professional educator whose primary responsibility is to educate, teach, guide, direct, train, assess, and evaluate pupils in early childhood education, basic education, and secondary school. While a professional is a job or activity performed by a person that becomes a source of income for life and needs knowledge, competency, or abilities that meet particular quality standards or norms, it also necessitates professional education (Muslich, 2007). Ongoing and continuous coaching is held to become a professional teacher, and teachers as a workforce must be appreciated and acknowledged for their expertise.

Previously, comparable investigations were undertaken by a number of researchers, including those conducted by (Handayani et al, 2021; Hardono et al, 2017; Herry et al, 2020; Lian \& Wardarita, 2021; Maryani et al, 2020). Previous study on the principal's leadership on teacher performance, as well as analyzing numerous other characteristics such as work ethic, is significant to the principal's leadership. However, several of these studies have not evaluated if the principal's leadership variable and the work ethic variable are assessed on teacher performance at the same time. This is what is novel in this study approach, as it can disclose the degree of the effect of the two factors on teacher performance if a joint test is conducted.

Several phenomena have emerged in the field of current education that impede the attainment of intended educational goals. The researchers' initial observations at the Madang Suku I District Junior High School, OKU Timur Regency, revealed that the phenomena that occur include the low work ethic of civil servant teachers as a result of the lack of a control system 
carried out by the principal, and the principal who does not know how to lead a good school. effective in order to strengthen the work ethic of civil servant instructors.

Based on the description above, it is vital to investigate the impact of the principal's leadership and the work ethic of civil servant instructors as one of the elements suspected of influencing teacher performance. On this basis, the researchers performed a study titled "The Influence of Principal Leadership and Civil Servant Teachers' Work Ethic on Teacher Performance."

\section{B. Methods}

This study took place in Madang Suku I District, OKU Timur Regency, which contains five junior high schools. The study was conducted from May to October 2021. The quantitative descriptive approach was utilized in this study to determine the partial influence of existing variables (Sugiyono, 2012). The quantitative research factors examined in this study were the principal's leadership (X1), civil servant teachers' work ethic (X2), and teacher performance (X3) (Y). The population in this study consisted of 48 persons, including principals, civil servant instructors, and students from five distinct schools, each with its own set of duties, attributes, and features. Because the population is tiny, the entire group is employed as a study sample.

A questionnaire was employed to collect correct data, which was backed by documentation. The validity and reliability of the research questionnaire were first assessed, either by expert review or statistically. The data collected during the study was processed before the hypothesis was tested, which is known as the analytical precondition test. One of the phases in measuring the existence or absence of data deviations for each variable is the prerequisite test. Prerequisite analysis tests are also required to assess whether or not data analysis for hypothesis testing may be resumed (Kesumawati and Aridanu, 2018). Normality, linearity, heteroscedasticity, and multicollinearity are the characteristics that must be satisfied before analysis can be performed for both prediction and hypothesis testing.

\section{Results and Discussion}

The collected study data has been recapitulated, processed, and evaluated in order to produce useful data. The average score for each characteristic achieved in the schools that comprised the research sample was fairly different. As a result, each sample group has the advantages and drawbacks of each of the factors evaluated. The requirements are checked first using this data. Begin by determining the normality of the data distribution. The normality test is used to determine if the distribution of data in a set of data or variables is normally distributed or not. In this study, the normality of the data was examined using the SPSS program, and the normality of the data was tested using the Kolmogorov-Smirnov test. The test findings received a significance value of 0.200 , which is more than 0.05 , indicating that the conditions for normality of the data distribution were met. The conclusion is that the data is normally distributed based on preset criteria, and that if the significance value is greater than 0.05 , the data is normally distributed. As a result, hypothesis testing may be accomplished using parametric statistical analysis.

In addition, heteroscedasticity testing was performed to see whether there was a variance inequality from the residuals for all data in the linear regression model. The heteroscedasticity test findings in this study indicated that there was no heteroscedasticity problem in the data 
Volume 2 (3) 2021

E-ISSN: 2723-6919 P-ISSN: 2746-0827

utilized since the data dispersed above and below or around the number 0 and did not establish a specific pattern. Another element that was checked was the data's linearity; for each test or variable, it was indicated that there was a substantial linear connection. This result is based on the significant values found in deviation from linearity greater than 0.05 , which are 0.183 and 0.120 , respectively. Multicollinearity tests yielded similar results, indicating that the data in this investigation did not exhibit multicollinearity symptoms. This conclusion is based on the Tolerance value of $0.752>0.10$ and the VIF value of 1.32910 .0 , both of which are required or criteria for the presence of multicollinearity. As a result, the regression model developed utilizing this study data is sound.

As is well known, researchers employ quantitative research methodologies or approaches to solve research challenges. The previously prepared hypothesis testing has been conducted out using this technique. Before beginning the study, the researcher examined the research data's necessary assertions, such as normality, heteroscedasticity, linearity, and multicollinearity.

The researchers discovered that the data were normally distributed, that there were no signs of heteroscedasticity in the existing data, that there were no symptoms of multicollinearity, and that the data showed a substantial linear connection. As a result, all of the prerequisites for conducting parametric statistical analysis have been satisfied. These processes are carried out so that the research results may give full and valuable information for stakeholders to utilize as the foundation for making suitable choices or policies.

Three hypotheses were investigated in this study using partial and simultaneous testing. It is clearer about the key issues to be considered in each exam since they are mentioned in the test discussion step by step.

\section{The Influence of the Principal's Leadership on Teacher Performance}

The research sample's maximum accomplishment was 97.60, while the lowest achievement for principals' leadership was 74.40. The study sample's highest score for principals' leadership was 78.40, attained by as many as 8 persons or 16.7 percent of the overall research sample. Only four people claimed that the principal's leadership was very excellent, and this achievement was based on an achievement score of more than 85.00.

The sample group's average accomplishment differs by a not-so-significant margin. Because the gap between the top and lowest scores isn't all that great, like in the case of SMP Negeri 1 Madang Suku I, which has the highest final average score of 82.27. While at SMP Negeri 4 Madang Suku I, the lowest final average score was 76.8. Because the difference in values is still included in the same interval, which is included in the good category for principle leadership, this value may be deemed to be a fair value.

The t-value for the principal's leadership variable is 4.225 , which is greater than the t-table value of 2.013, indicating that the alternative hypothesis (Ha) for testing the first hypothesis is accepted. As a result, the principal's leadership is said to have a considerable impact on the performance of state junior high school teachers in Madang Suku 1 District, OKU Timur Regency. Another source of evidence is the significance value of 0.0000 .05 , which indicates that the alternative hypothesis $(\mathrm{Ha})$ for $\mathrm{H} 1$ is accepted. The regression equation derived from the study data is $=46,412+0,426 \times 1$. 
The magnitude of the association between the principal's leadership and teacher performance is 52.9 percent, which falls into the category of a pretty strong relationship. The magnitude of the effect of the principal's leadership variable on teacher performance is 28.0 percent, indicating that it has a modest influence. The findings of this study also complement prior studies, such as that of Sucipno et al. (2017), which found that principal leadership had a favorable impact on maximizing teacher performance.

Similarly, Murtiningsih and Lian (2017) discovered that principals, as decision makers, play a significant impact in boosting teacher performance. Another study backed by these findings is the research of Lukman et al, (2020), which found that principal leadership can improve teacher effectiveness. As stated by Handayani et al, (2021), it is critical for a school administrator to lead in a positive manner in order to improve teacher performance. According to As'ad et al. (2018) and Kurniati \& Minsih (2016), principal leadership influences not just teacher effectiveness but also student accomplishment. Sukmaswati et al, (2020) verified the same thing.

It may also consider the research done by Umami et al, (2020), Atmojo et al, (2021), and Palupi et al, (2021), all of which investigated principal leadership, which obviously has a favorable influence on teacher performance. As a result, effective leadership is expected of a school principal. Harmendi et al, (2021), Juniarti et al, (2020), and Sauri et al, (2018) underline that the consistency of the primary leadership variable has been tested to have a favorable and substantial influence on maximizing teacher performance in carrying out their key activities and functions.

\section{The Influence of Teacher's Work Ethic on Teacher's Performance}

The research sample's best accomplishment for the work ethic variable was 86.15 , while the lowest achievement for the teacher's work ethic was 76.15 . The study sample received the highest score for instructors' work ethic, 76.15 , from as many as 12 participants, or $25 \%$ of the overall research sample. It may also be explained that there is just one individual who says the teacher's work ethic is in the very good category, and the achievement is based on a score of more than 85.00 .

The average value of teachers' work ethic differed throughout the schools that comprised the research sample. However, the variations that do occur are minor. Because the gap between the top and lowest scores isn't all that great, like in the case of SMP Negeri 1 Madang Suku I, which has the highest final average score of 81.42. At SMP Negeri 5 Madang Suku I, the lowest final average score was 76.5. This value may be deemed to be fair because the difference in values is still included in the same interval, which is in the good category for the teacher's work ethic.

The data analysis yielded a t-count value of 5.713 for the teacher's work ethic variable. This value indicates that the t-table value is 2.013, implying that t-count $>\mathrm{t}$-table; 5,713 $>2,013$. Based on this, the alternative hypothesis is accepted, implying that teachers' work ethic has a positive and substantial effect on the performance of State Junior High School instructors in Madang Suku 1 District, OKU Timur Regency. To back up these findings, the significance value is 0.0000 .05 , indicating that the alternative hypothesis $(\mathrm{Ha})$ is accepted and the statistical hypothesis $(\mathrm{H} 0)$ is rejected. The regression equation derived from the study data is $=29.483+$ $0.639 \times 2$. 
Volume 2 (3) 2021

E-ISSN: 2723-6919 P-ISSN: 2746-0827

The size of the association between teacher work ethic and teacher performance is 64.4 percent, according to the correlation coefficient. The size of the association falls into a reasonably narrow range. The determinant coefficient or magnitude of the impact of the teacher's work ethic variable on the performance of State Junior High School instructors in Madang Suku 1 District, OKU Timur Regency is 41.5 percent, placing it in the category of moderate influence.

The findings of this study also complement Marlinah's (2019) research, which found that a teacher's work ethic has a direct impact on student accomplishment, which, of course, begins with a good influence on the teacher's performance.

\section{The Impact of the Principal's Leadership and the Work Ethic of Teachers on Teacher Performance}

The research sample's maximum achievement was 91.20, while the lowest achievement for instructor performance was 76.00. The highest value obtained by the study sample in terms of instructor performance was 80.00 , which was attained by as many as 9 participants, or 18.8 percent of the overall research sample. There are just two persons whose performance falls into the very good category; the achievement is based on a value greater than 85.00.

The average value of teacher performance differed between the schools that comprised the research sample. However, the variations that do occur are minor. Because the gap between the top and lowest scores isn't all that great, like in the case of SMP Negeri 1 Madang Suku I, which has the highest final average score of 81.76. SMP Negeri 5 Madang Suku I had the lowest final average score of 77.78. Because the difference in values is still included in the same interval, which is included in the good category for the performance of State Junior High School teachers in Madang Suku I District, this figure may be deemed to be a fair value.

The F-count is 20,163 > F-table is 3.204, indicating that the principal's leadership and work ethic have a good and substantial impact on the performance of State Junior High School instructors in Madang Suku 1 District, OKU Timur Regency. The significance value found, namely 0.0000 .05 , indicates that the alternative hypothesis $(\mathrm{Ha})$ is accepted and the statistical hypothesis (H0) is rejected. The simultaneous regression equation derived from the test data is $=22.517+0.223 \mathrm{X} 1+0.502 \mathrm{X} 2$.

Taken combined, the principal's leadership and teacher work ethic have a 68.7 percent link with the performance of State Junior High School teachers in Madang Suku 1 District, OKU Timur Regency, indicating a pretty tight relationship. Principal leadership and work ethic have a considerable effect on the performance of State Junior High School teachers in Madang Suku I District, OKU Timur Regency by 47.3 percent, placing it in the category of rather high influence.

The findings of this study back with recent research by Rinaldi (2016), which found that a person's work ethic and effective leadership had a substantial impact on a person's performance. According to Marlinah (2019), learning results can be positively affected if a teacher has a strong work ethic and is supported by strong principle leadership. Of course, excellent teacher performance is the starting point for this success. 


\section{Conclusion}

Based on the findings of the data analysis during the research process, several conclusions can be drawn from this study, including the fact that the alternative hypothesis (Ha) for testing the first hypothesis is declared accepted, implying that the principal's leadership variable has a positive and significant influence on the performance of state junior high school teachers in Madang Suku I District, OKU Timur Regency. The effect of the principal's leadership variable on teacher performance is classified as modest. The alternative hypothesis (Ha) for testing the second hypothesis is accepted, implying that the work ethic variable of teachers has a positive and substantial effect on the performance of State Junior High School instructors in Madang Suku 1 District, OKU Timur Regency. The effect of the teacher's work ethic variable on teacher performance is in the moderate range. The alternative hypothesis (Ha) for testing the third hypothesis is accepted, implying that the principal's leadership variable and the teacher's work ethic have a positive and substantial impact on the performance of State Junior High School instructors in Madang Suku I District, OKU Timur Regency. The effect of the factors of the principal's leadership and the teacher's work ethic on the teacher's performance is in the quite high category.

\section{E. Acknowledgement}

We thank to State Junior High School instructors in Madang Suku I District, OKU Timur Regency, Rector Universitas Bengkulu, Rector Universitas PGRI Palembang, and friends of graduate program educational management Universitas PGRI Palembang who have supported us to do this project.

\section{References}

As'ad, M., Anita, E., \& Yulianto. (2018). Pengaruh Kepemimpinan Kepala Sekolah dan Kompetensi Pedagogik Guru Terhadap Hasil Belajar Siswa SMK PGRI II Ciledug PAda Kota Tanggerang Banten [The Influence of Principal Leadership and Teacher Pedagogic Competence on Student Learning Outcomes at SMK PGRI II Ciledug in Tangerang City, Banten]. Transparansi: Jurnal Ilmiah Ilmu Administrasi; 1(2) , 149-157.

Atmojo, H. B., Lian, B., \& Mulyadi. (2021). Peran Kepemimpinan dan Profesional Guru Terhadap Perbaikan Mutu Pembelajaran [The Role of Teachers' Leadership and Professionals in Improving the Quality of Learning]. Jurnal Educatio, 7(3), 744-752.

Firman, F., Fitria, H., \& Rohana, R. (2021). The Influence of School Leadership Style and Teacher's Motivation toward Teacher's Performance. Journal of Social Work and Science Education, 2(1), 1-10. https://doi.org/10.52690/jswse.v2i1.134

Handayani, E., Lian, B., \& Rohana. (2021). Kinerja Guru Ditinjau Dari Pengaruh Budaya Organisasi dan Gaya Kepemimpinan Kepala Sekolah [Teacher Performance Judging from the Influence of Organizational Culture and Principal's Leadership Style]. JMKSP (Jurnal Manajemen, Kepemimpinan, dan Supervisi Pendidikan), 77-87.

Hardono, Haryono, \& Yusuf, A. (2017). Kepemimpinan Kepala Sekolah, Supervisi Akademik, dan Motivasi Kerja dalam Meningkatkan Kinerja Guru [Principal Leadership, Academic 
Supervision, and Work Motivation in Improving Teacher Performance]. Educational Management, 6(1), 26-33.

Harmendi, M., Lian, B., \& Wardarita, R. (2021). Pengaruh Gaya Kepemimpinan Kepala Sekolah dan Motivasi Kerja Terhadap Kinerja Guru [The Influence of Principal's Leadership Style and Work Motivation on Teacher Performance]. PRODU: Prokurasi Edukasi Jurnal Manajemen Pendidikan Islam, 2(2).

Herry., Lian, B., \& Fitriani, Y. (2020). Pengaruh Kepemimpinan Kepala Sekolah dan Komitmen Guru terhadap Kinerja Profesional Guru [The Effect of Principal Leadership and Teacher Commitment on Teacher Professional Performance]. Jurnal Pendidikan Tambusai, 4(2).

Juniarti, E., Ahyani, N., \& Ardiansyah, A. (2020). Pengaruh Kepemimpinan Kepala Sekolah dan Disiplin Guru terhadap Kinerja Guru [The Influence of Principal Leadership and Teacher Discipline on Teacher Performance]. Journal of Education Research, 1(3).

Kesumawati, N., \& Aridanu, I. (2018). Statistik Parametrik: Penelitian Pendidikan [Parametric Statistics: Educational Research]. Palembang: NoerFikri Offset.

Kristiawan, M., Safitri, D., Lestari, R. (2017). Manajemen Pendidikan [Education Management]. Yogyakarta: Deepublish.

Kurniati, F., \& Minsih. (2016). Pengaruh Kepemimpinan Kepala Sekolah dan Kommpetensi Guru Terhadap Prestasi Belajar Siswa di SD Muhammdiyah Baturan [The Influence of Principal Leadership and Teacher Competence on Student Achievement at SD Muhammdiyah Baturan]. Surakarta: Universitas Muhammadiyah Surakarta.

Lian, B., \& Wardarita, R. (2021). Pengaruh Kepemimpinan Kepala Sekolah dan Budaya Organisasi Terhadap Kinerja Guru SMP Se-Kecamatan Sako Palembang [The Influence of Principal Leadership and Organizational Culture on the Performance of Middle School Teachers in Sako Palembang District]. Jurnal Pendidikan, 1(9, 1-10.

Lukman., Lian, B., \& Sari, A. (2020). The Influence of Principal's Leadership and Work Motivation toward Teacher's Performance. International Journal of Progressive Sciences and Technologies, 22(1), 376-379.

Marlinah, H. (2019). Pengaruh Kepemimpinan Kepala Sekolah, Kompetensi Guru dan Etos Kerja Guru Terhadap Prestasi Belajar Siswa (Sekolah Menengah Pertama Negeri Tanggerang Selatan di kec.Pamulang) [The Influence of Principal Leadership, Teacher Competence and Teacher Work Ethic on Student Learning Achievement (South Tangerang State Junior High School in Pamulang sub-district)]. Wiga: Jurnal Penelitian Ilmu Ekonomi, 9(1), 36-42.

Maryani, A., Lian, B., \& Wardarita, R. (2020). Pengaruh Gaya Kepemimpinan Kepala Sekolah dan Budaya Organisasi Sekolah terhadap Kinerja Guru. Journal of Innovation in Teaching and Instructional Media, 1(1), 18-25. 
Volume 2 (3) 2021

E-ISSN: 2723-6919 P-ISSN: 2746-0827

Murtiningsih, \& Lian, B. (2017). Proses pengambilan keputusan kepala sekolah terhadap peningkatan kinerja guru SMP [Principal's decision-making process on improving the performance of junior high school teachers]. JMKSP (Jurnal Manajemen, Kepemimpinan dan Supervisi Pendidikan), 2(1), 87-96.

Muslich, M. (2007). Sertifikasi Guru Menuju Profesionalisme Pendidik [Teacher Certification Towards Educator Professionalism]. Jakarta: Bumi Askara.

Palupi, E., Lian, B., \& Sari, A. (2021). Strategi Kepemimpinan Kepala Sekolah dalam Meningkatkan Mutu Guru [Principal's Leadership Strategy in Improving Teacher Quality]. Cahaya Pendidikan, 7(1), 51-62.

Rahmadi, B., Arafat, Y., \& Setiawan, A. A. (2021). Principal Leadership in the Development of Teacher Pedagogical Competence . Journal of Social Work and Science Education, 2(2), 117-126. https://doi.org/10.52690/jswse.v2i2.231

Rinaldi, M. (2016). Pengaruh Disiplin Kerja dan Etos Kerja serta Gaya Kepemimpinan Situasional Terhadap Pegawai di Kantor Bdan Penanggulangan Bencana Daerah Kota Palu [The Influence of Work Discipline and Work Ethic and Situational Leadership Style on Employees at the Regional Disaster Management Agency Office of Palu City]. Katalogis, 4(10).

Sauri, A. S., Widyasari, \& Sesrita, A. (2018). Pengaruh Kepemimpinan Kepala Sekolah Terhadap Kinerja Guru [The Effect of Principal's Leadership on Teacher Performance]. Tadbir Muwahhid, 2(1).

Sucipno, Sasongko, R., \& Zakaria. (2017). Pengaruh Kepemimpinan Pembelajaran Kepala Sekolah dan Kepuasan Kerja Terhadap Kinerja Guru di SMP [The Effect of Principal's Learning Leadership and Job Satisfaction on Teacher Performance in Junior High Schools]. Manajer Pendidikan: 11(1).

Sudarminta. (2000). Tantangan dan Permasalahan Pendidikan di Indonesia. Transformasi Pendidikan Memasuki Milenium Ketiga [Challenges and Problems of Education in Indonesia. Educational Transformation Entering the Third Millennium]. Yogyakarta: Kanisius.

Sudjana, N., \& Ibrahim. (2010). Penelitian dan Penilaian Pendidikan [Educational Research and Assessment]. Bandung: Sinar Baru Algeria.

Sugiyono. (2012). Metode Penelitian Pendidikan, Pendekatan Kuantitatif, Kualitatif dan R\& $D$ [Educational Research Methods, Quantitative, Qualitative and R\&D Approaches]. Bandung: Alfabeta.

Sukmaswati, I., Lian, B., \& Wardiah, D. (2020). The Influence of Principal's Leadership and Teacher's Performance on Student'Achievement. International Journal of Progressive Sciences and Technologies, 20(1), 247-254. 
Journal of Social Work and Science Education

Volume 2 (3) 2021

E-ISSN: 2723-6919 P-ISSN: 2746-0827

Susilawati, S., Fitria, H., \& Eddy, S. (2021). The Effect of Principal's Leadership Style and Teacher's Job Satisfation towards Teacher's Performance. Journal of Social Work and Science Education, 2(1), 42-51. https://doi.org/10.52690/jswse.v2i1.192

Syah, M. (2011). Psikologi Belajar [Learning Psychology]. Jakarta: Raja Grafindo Persada.

Umami, S., Lian, B., \& Missriani. (2020). Pengaruh Kepemimpinan dan Motivasi Kerja Guru Terhadap Disiplin Kerja [The Influence of Teacher Leadership and Work Motivation on Work Discipline]. JMKSP: Jurnal Manajemen, Kepemimpinan, dan Supervisi Pendidikan, 52-66. 